\title{
Mining environmental liabilities: a potential source of metal contamination for freshwater ecosystems in Costa Rica
}

Pasivo ambiental minero: una fuente potencial de contaminación por metales para los ecosistemas de agua dulce en Costa Rica

\author{
Johanna Rojas Conejo ${ }^{1}$ \\ Universidad Nacional, Costa Rica \\ Andrea Suárez Serrano ${ }^{2}$ \\ Universidad Nacional, Costa Rica \\ Christian Golcher Benavides ${ }^{3}$ \\ Universidad Nacional, Costa Rica \\ Francisco Picado Pavón ${ }^{4}$ \\ Universidad Nacional Autónoma de Nicaragua, Nicaragua \\ Cornelis A. M. van Gestel \\ Vrije Universiteit, Amsterdam, The Netherlands \\ Guillermo Durán Sanabria \\ Independent Consultor, Costa Rica
}

1 MSc. Johanna Rojas Conejo. Researcher. Centro de Recursos Hídricos para Centroamérica y el Caribe (HIDROCEC-UNA). Universidad Nacional, Costa Rica. johanna.rojas.conejo@una.ac.cr. (D) https://orcid. org/0000-0002-9001-3694

$2 \mathrm{PhD}$. Andrea Suárez Serrano. Researcher / Coordinator. Centro de Recursos Hídricos para Centroamérica y el Caribe (HIDROCEC-UNA). Universidad Nacional, Costa Rica. andrea.suarez.serrano@una.cr. ID https:// orcid.org/0000-0002-1930-3381

3 PhD. Christian Golcher Benavides. Researcher. Centro de Recursos Hídricos para Centroamérica y el Caribe (HIDROCEC-UNA). Universidad Nacional, Costa Rica. christian.golcher.benavides@una.ac.cr. (D) https://orcid.org/0000-0001-6738-9557

4 Dr. Francisco Picado Pavón. Researcher / Coordinator in Laboratorio de Mercurio Ambiental. Centro para la Investigación en Recursos Acuáticos de Nicaragua(CIRA/UNAN-Managua). Universidad Nacional Autónoma de Nicaragua. francisco.picado@cira.unan.edu.ni. (iD https://orcid.org/ 0000-0002-3698-5214

5 Prof.Dr. Cornelis A. M. van Gestel. Researcher. Department of Ecological Science, Faculty of Science, Vrije Universiteit, Amsterdam, The Netherlands. kees.van.gestel@vu.nl. iD https://orcid.org/0000-0002-5651-0208

6 M.Sc. Guillermo Durán Sanabria. Goegraphic Information Systems Specialist. Independent Consultor. Costa Rica.Gds.506@gmail.com. (iD https://orcid.org/0000-0002-1944-9524 


\begin{abstract}
Metal mining in Costa Rica, and use of toxic substances in this activity, has occasionally resulted in the negligent abandonment of waste structures containing significant amounts of toxic metals. These structures have been exposed to oxidation and weathering, resulting in the environmental release of metals, thus affecting the quality of the surrounding freshwater ecosystems. The objective of the investigation was to determine to what extent the abandoned mining liabilities in Líbano de Tilarán, Guanacaste, are a potential source of metal contamination for the waters, sediments and benthic macroinvertebrates of the San José and Cañas Rivers. The possible consequences for the environment associated with the presence of mining wastes were quantitatively and qualitatively assessed through the amounts of metals present in the wastes and leachate. Infiltration tests were carried out and a wet cell kinetic test allowed describing the processes and chemical reactions that are likely to occur in mining wastes during rain, associated with the loading of metals in leachate. The presence of pyrite $\left(\mathrm{FeS}_{2}\right)$, which favors the acidification of the medium and the release of metals, was shown by X-ray diffraction tests on samples of the waste materials. The results show a high content of metals (37.8 tons of lead, 20.2 tons of arsenic and 0.4 tons of cadmium) from the total of $\sim 106000$ tons in mining liabilities, the solubilization of these and other metals in an oxidizing acid medium (pH: 4.16, EC: $3620 \mu \mathrm{s} / \mathrm{cm}$ and ORP: $275 \mathrm{mV}$ ) during the dry-rainy season transition and an important load of metals $(277 \mathrm{~kg} /$ month of zinc, $234 \mathrm{~kg} /$ month of magnesium, $165 \mathrm{~kg}$ / month of aluminum, $96.1 \mathrm{~kg}$ / month of iron, $2.68 \mathrm{~kg} /$ month of cadmium, $0.90 \mathrm{~kg} /$ month of arsenic and $0.22 \mathrm{~kg} /$ month of lead) in leachates arriving to the San José River in September. This investigation showed that the abandoned mining liabilities in Líbano are a potential source of metal contamination for the surrounding freshwater ecosystems.
\end{abstract}

Keywords: handling; leachate; metal; mining; liabilities

\title{
Resumen
}

La minería de metales en Costa Rica, y el uso de sustancias tóxicas en esta actividad, ocasionalmente ha resultado en el abandono negligente de estructuras de desechos que contienen cantidades significativas de metales tóxicos. Estas estructuras que han quedado expuestas a la oxidación y a la meteorización resultan en la liberación ambiental de metales, lo cual propicia la afectación en la calidad natural de los cuerpos de agua superficiales circundantes. El objetivo de la investigación fue determinar que los pasivos mineros abandonados en el Líbano de Tilarán, Guanacaste, son una fuente potencial de contaminación por metales para las aguas, sedimentos y macroinvertebrados bentónicos de los ríos San José y Cañas. Las posibles consecuencias para el medio ambiente asociadas con la presencia de desechos mineros se evaluaron cuantitativa y cualitativamente a través de las cantidades de metales presentes en los desechos y lixiviados. Se realizaron pruebas de infiltración y una prueba cinética de celda húmeda permitió describir los procesos y las reacciones químicas que pueden ocurrir en los desechos mineros durante la lluvia, asociados con la carga de metales en el lixiviado. La presencia de pirita $\left(\mathrm{FeS}_{2}\right)$ favorece la acidificación del medio y la liberación de metales, se destaca mediante pruebas de difracción de rayos $\mathrm{X}$ en muestras de los materiales de desecho. Los resultados muestran un alto contenido de metales (37.8 toneladas de plomo, 20.2 toneladas de arsénico y 0.4 toneladas de cadmio) del total de $\sim 106000$ toneladas en pasivos mineros, la solubilización de estos y otros metales en un medio ácido oxidante (pH: 4.16, CE: $3620 \mu \mathrm{s}$ / cm y ORP: $275 \mathrm{mV}$ ) durante la transición de la estación seca y lluviosa y una carga importante de metales $(277 \mathrm{~kg} /$ mes de zinc, $234 \mathrm{~kg} /$ mes de magnesio, $165 \mathrm{~kg} /$ mes de aluminio, $96.1 \mathrm{~kg} / \mathrm{mes}$ de hierro, $2.68 \mathrm{~kg}$ / mes de cadmio, $0.90 \mathrm{~kg} /$ mes de arsénico y $0.22 \mathrm{~kg} /$ mes de plomo) en lixiviados que llegan al río San José en septiembre. Esta investigación mostró que los pasivos mineros abandonados en el Líbano son una fuente potencial de contaminación por metales para los ecosistemas de agua dulce circundantes.

Palabras claves: lixiviado; manejo; metal; minería; pasivo 


\section{Introduction}

Gold mining liabilities may negatively affect the environment by contaminating soils, groundwater, and surface water with metals (Naicker, Cukrowska \& McCarthy, 2003; Singh, Zeng \& Chen, 2005; Pruvot, Douay, Herve, \& Waterlot, 2006; Navarro, Pérez-Sirvent, Martínez-Sanchez, Vidal, Tovar \& Bech, 2008) and consequently threaten the health of the people that use these resources. Human exposure to metals, such as Copper $(\mathrm{Cu})$, Lead $(\mathrm{Pb})$ and Cadmium $(\mathrm{Cd})$, in leachates from mining wastes is associated with some diseases. The effects of cadmium exposure may occur primarily in the form of kidney damage but possibly also bone effects and fractures (Jarup, 2003). Even if the concentrations of these metals in mining waste are low, the problem persists, as the magnitude of the problem also depends on the amount of waste (Rösner \& Van Schalkwyk, 2000), the environmental conditions to which they are exposed and the mobility of the metals. In tropical environments, where temperatures are generally higher than $18^{\circ} \mathrm{C}$ and rainfall is intense, the mobility of metals tends to increase significantly. Besides, erosion and oxidation of minerals present in mining waste create acidic conditions (Rösner \& Van Schalkwyk, 2000; Naicker et al., 2003), facilitating the mobilization of metals into surface and groundwater (Naicker et al., 2003; Candeias et al., 2011; Craw, 2000).

In the past, mining activity in Costa Rica has left abandoned mining wastes, such as those found in the town of Líbano located in Tilarán, Guanacaste province (Singer, Norman, Bagby, Cox \& Ludington, 1990), whose activity ceased at the end of the 1990s and currently could constitute a potential contamination risk for the San José River. At present, the degree of conjugation between factors such as the intense exposure of these wastes to erosion and the permanent oxidation process to which they are subjected is unknown. Both factors promote the removal of significant amounts of contaminating material through the formation of runoffs and leachates with low pH values (Rösner \& Van Schalkwyk, 2000). The leachate from the abandoned mine is frequently enriched with toxic elements, but its movement off-site is diffuse (Kyungmin, Juhee \& Seunghun, 2018).

The mining waste resulting from the physical and/or chemical extraction of the mineral of interest, primary mineral, is composed mainly of gangue minerals and secondary minerals of little economic interest. As a product of the crushing for the extraction of gold $(\mathrm{Au})$ and silver $(\mathrm{Ag})$, 
these rock wastes are formed by very fine particles and exposed to a large surface area subject to oxidation reactions (Jambor, 1994). They may contain significant amounts of calcium oxide $(\mathrm{CaO})$, added during the neutralization process, and other metals resulting from the chemical reactions that took place between their mineral components and the reagents that were added during the same process (Seal II \& Foley, 2002).

Mining wastes may also contain sulfides (Rösner \& Van Schalkwyk, 2000) associated with deposits, which are responsible for creating acidic conditions during the formation of leachates. For example, the presence of pyrite ore $\left(\mathrm{FeS}_{2}\right)$ in wastes leads to oxidation processes that cause acid drains (González, Sánchez, Márquez, Lizárraga, \& Durán, 2008; Nicholson, 1994). The epithermal deposit found in Líbano of Tilaran, which is of the Sado type (Singer et al., 1990), was formed from low-sulphurization chemical fluids, which implies that they are reduced $\left(\mathrm{H}_{2} \mathrm{~S}\right)$ and have a $\mathrm{pH}$ close to neutral. Low-sulfidation deposits may contain silver $(\mathrm{Ag})$, minor amounts of lead $(\mathrm{Pb})$, zinc $(\mathrm{Zn})$ and copper $(\mathrm{Cu})$, and associated minerals such as quartz, pyrite, and galena (Camprubí, González-Partida \& Levresse, 2003).

The hazard of mining waste and the leachate will depend on the toxicity of the waste and its geo availability and bioavailability. Both are determined by the geology, concentrations of metals and metalloids, the action of biological and geochemical factors on the waste, and the presence of organic matter in the soil (Plumlee \& Nash, 1995). The amount of mining waste and the vulnerability of the affected surface waters are factors that influence the hazardousness of the waste. Therefore, the main objective of this study is to assess the size of the problem. The study included quantifying the amount of mining waste, its characterization and assessment of the quality of leachate formed. Final aim was to demonstrate to what extent this environmental liability is a potential source of contamination of the surrounding surface freshwater ecosystem.

\section{Methodology}

\section{Study area}

The old "Esperanza" mine is in Líbano, $8 \mathrm{~km}$ southeast of Tilarán in Costa Rica. Industrial and artisanal mining activity in this area took place between 1907 and 1986 with the exploitation of 5 epithermal veins (Castillo, 1997). At present, the mining liabilities resulting from this activity continue 
to be abandoned in Líbano, accumulated at 296 meters above sea level on the banks of the San José River, an important tributary (base flow $0.03 \mathrm{~m}^{3} / \mathrm{s}$ ) of the Cañas River sub-basin that flows into the Tempisque-Bebedero Basin, North Pacific Region of Costa Rica (Figure 1). This is an area dominated by alluvial and colluvial surface deposits, of recent age, which also include landslide deposits, mudstones, swamp and beach deposits (Arce, 2004). Líbano is located at the confluence of several mountain streams at risk of detrital flows and flooding (Arce, 2004). The geology of the area is dominated by andesitic lava, tuff and lapilli tuff of the Aguacate Group, which present pervasive propylitic alteration (Cooke, 1987).

The annually average rainfall in this area is $1805,1 \mathrm{~mm}$, and the highest rainfall occurs in September and October (ICE, 2015). Six ranges of average temperatures predominate; the lowest being $17^{\circ} \mathrm{C}$ and the highest $27^{\circ} \mathrm{C}$ (IMN, 2010).

Figure 1. Sub-basin of the Cañas River. Location of mining waste in Líbano, Costa Rica

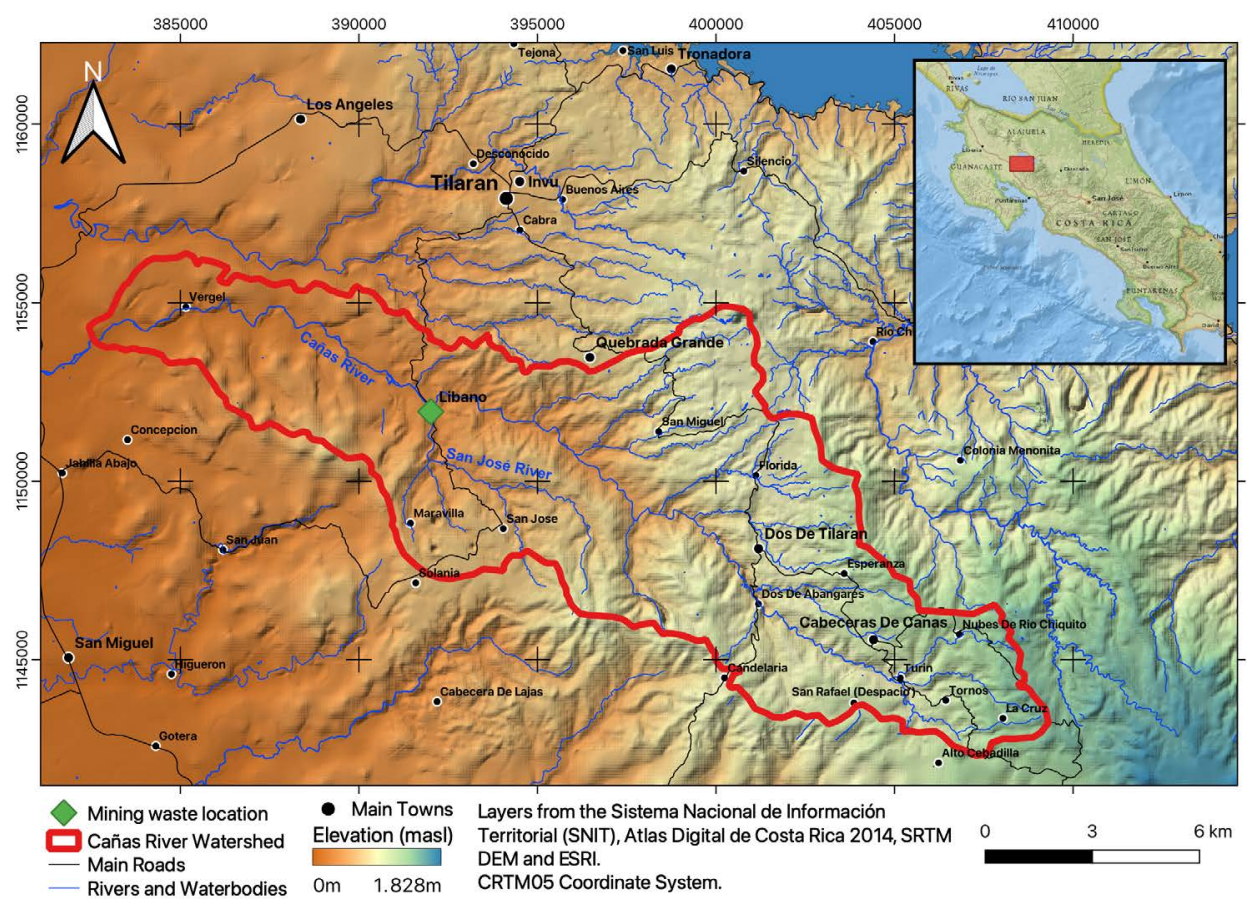




\section{Sizing and characterization of mining waste}

Volume and sampling of mining waste

A tape measure was used to measure the area of the mining waste pile in greater detail. The approximate heights of the mound were measured with sinkers from the surface to the base of the San José River. The average heights $(\mathrm{H})$ and surface areas were used to estimate the volume (V) of the waste, assuming a rectangular base.

The area of the upper part of the waste was divided into two plots (Lib A and Lib B), each measuring approximately $3.909 \mathrm{~m}^{2}$. In a triangular arrangement ( $3 \mathrm{~m}$ distance from one point to another), in the center of each plot, three boreholes were drilled, each $1 \mathrm{~m}$ deep, from which a composite sample of $\sim 450 \mathrm{~g}$ was obtained (150 g extracted every $30 \mathrm{~cm}$ deep). The three samples obtained from each plot were separately homogenized by hand to obtain two representative samples (Lib A and Lib B). Both samples were placed in plastic bags for laboratory analysis and kinetic testing.

\section{Minerals in mining waste}

X-Ray Diffraction Analysis (XRD) was performed on Lib A and Lib B samples with an X-Ray Diffractometer (Bruker, D4 Endeavor) to identify the minerals present in the mine waste. To identify the minerals from the crystalline powder diffraction diagrams, diffraction patterns contained in the JCPDS (Joint Committee for Powder Diffraction Sources) database of the ICDD (International Center for Diffraction Data,1997) (www.icdd. com) were used.

\section{Metal concentration in mining waste}

Before obtaining the composite samples Lib A and Lib B, $1.5 \mathrm{~g}$ of each of the 3 samples obtained from each plot were analyzed following the procedure 3030E APHA (1995), for total metal concentrations. Samples were digested with a mixture of $1.5 \mathrm{ml}$ of $\mathrm{HNO}_{3}(69 \%)$ and $4.5 \mathrm{ml}$ of $\mathrm{HCl}$ $(37.5 \%)$ at $85{ }^{\circ} \mathrm{C}$. The digests were analyzed by atomic absorption spectrophotometry (Perkin Elmer, AAnalyst 800) with flame technique for $\mathrm{Cu}$ and $\mathrm{Mn}$, with graphite furnace for $\mathrm{As}, \mathrm{Al}, \mathrm{Cd}, \mathrm{Cr}$ and $\mathrm{Pb}$, and by cold steam (Perkin Elmer, MHS 15) for Hg. During the analyzes, control standards were used with certificates drawn to the NIST, read at the beginning and at the end of each run; these control standards were also used to prepare fortified samples, with both values obtaining recovery percentages of 90$110 \%$. The sample blank used in this analysis corresponds to the one that 
was subjected to the same digestion as the waste samples. A calibration blank was also used in the laboratory. Calibration curves were performed with a total of 6 to 8 standards.

2.2.4 Particle density and estimation of the amount of mining waste

The particle density $\left(\mathrm{d} \rho ; \mathrm{kg} / \mathrm{m}^{3}\right)$ of the mining waste was determined on 5 replicates of $200 \mathrm{~g}$ (dry weight) of a mixture of Lib A and Lib B samples.

The total mass of material (M: $\mathrm{kg}$ ) was estimated as:

$$
M=d \rho * V \quad \text { (E. } 1)
$$

$\mathrm{V}$ : volume (V) of mining waste, d $\rho$ : particle density $\left(\mathrm{d} \rho: \mathrm{kg} / \mathrm{m}^{3}\right)$

\section{Quantity of metals present in mining waste}

The amount of mass (ton) of each metal present in the mining waste was estimated using the average of the concentrations $(\mathrm{mg} / \mathrm{kg})$ determined in the three sub-samples of the composite samples Lib A and Lib B $\left(\mathrm{C}_{\text {metal }}\right)$, and the total amount of mining waste (M: $\mathrm{kg}$ ).

\section{Leaching and loading of contaminants}

Wet cell kinetic test

To assess what effect oxidation has on the waste material, a waste

Figure 2. Moisture cell for the kinetic test used to determine effects of oxidation on leaching quality produced by mining waste materials

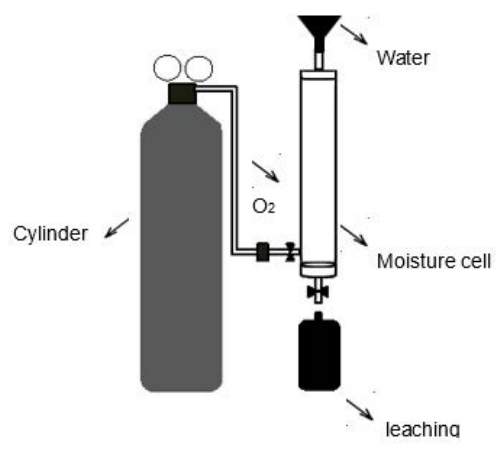
sample was subjected to the environmental conditions of the site. A kinetic test was carried out in two cycles, lasting 7 and 6 days each, using a moisture cell according to Sobek, Schuller, Freeman and Smith (1978). Using this test also information was obtained on the resulting acidic conditions and the quality of the leachate produced.

The moisture cell (Figure 2) was constructed with a $60 \mathrm{~cm}$ long, $7.6 \mathrm{~cm}$ internal diameter PVC pipe. Three 
hoses were fitted to this pipe: one at the top for water intake and air outlet, one at the bottom for the output of the leachate produced, and a third located laterally at the bottom for the intake of pressurized air (100 lpm). An oxygen cylinder incorporated into the system using a flow meter and a humidity trap was used as an air source.

On the first day of testing, $200 \mathrm{~g}$ of a composite sample obtained from the mixture of Lib A and Lib B samples was placed in the cell. The lateral dry air inlet and the upper air outlet were left open during the first three days of each cycle, the inlet for humid air on the following three days. The air was made to flow from the bottom of the cell upwards through the entire sample. On the last day of each cycle, the sample was leached with $450 \mathrm{ml}$ of distilled water (corresponding to $98.7 \mathrm{~mm} / \mathrm{m}^{2}$ ) and the respective leachates, Lix 1 and Lix 2, were collected and stored at $4^{\circ} \mathrm{C}$. Both leachates were measured for dissolved oxygen, $\mathrm{pH}$ and electrical conductivity using multi-parameter equipment (OAKLON, 600 Series) and electron transfer (ORP) (Thermo scientific ORP, H00862 Series). In addition, total $\mathrm{Fe}$ and $\mathrm{SO}_{4}^{2+}$ concentrations were determined by visible ultraviolet spectrophotometry (APHA, 2005).

A composite sample obtained from Lix 1 and Lix 2 was digested with $1: 1 \mathrm{HCl}(37.5 \%)$ and $\mathrm{HNO}_{3}(69 \%)$ for the analysis of metals (Al, As, $\mathrm{Ba}, \mathrm{Cd}, \mathrm{Cu}, \mathrm{Cr}, \mathrm{Fe}, \mathrm{Mg}, \mathrm{Mn}, \mathrm{Hg}, \mathrm{Ni}, \mathrm{Ag}, \mathrm{Pb}, \mathrm{Zn}$, and V). This analysis was performed through inductively coupled plasma optical emission spectrometry (ICP-OES Agilent Series 715 Radial) following Standard Methods (APHA, 2005). All samples were read in duplicate, using a control for each measurement range.

Mine waste infiltration capacity

Infiltration tests were conducted at three sites representative of the entire waste area, at $30 \mathrm{~m}$ distance from each other, following Porchet Method or Well Permeameter Method (USBR 7300-89). An auger was used to make three holes $45 \mathrm{~cm}$ deep. Each hole was saturated with water as many times as necessary until the level slowly dropped. The hole was then filled again with water, and with a tape measure and a millimeter ruler the decrease of the water $(\mathrm{cm})$ was measured every minute for $10 \mathrm{~min}$, and then every 5 min until $1 \mathrm{~h}$ was completed.

The infiltration capacity $(f: \mathrm{cm} / \mathrm{min})$ of the mining waste was estimated from the reduction rate of the water level and the diameter of the hole. 


\section{Metal leaching from mining waste}

The amounts of water ( $\mathrm{mm} / \mathrm{month})$ infiltrating in the mining waste and draining superficially and/or evaporating were determined with the infiltration capacity $(f: \mathrm{cm} / \mathrm{min})$ and the equations proposed by Schosinsky and Losilla (2000). The monthly average precipitation rates recorded from 2001 to 2015 at the meteorological station in Líbano (Table 1) were used in the estimates of leachate generated from mining waste.

Table 1. Monthly average rainfalls, P (mm/month), from 2001 to 2015, recorded at the weather station of Líbano in Costa Rica (ICE, 2015)

\begin{tabular}{|c|c|c|c|c|c|c|c|c|c|c|c|c|}
\hline Month & Jan & Feb & Mar & Apr & May & Jun & Jul & Aug & Sept & Oct & Nov & Dec \\
\hline Rainfall & 5.3 & 7.6 & 6.7 & 26.2 & 212.5 & 250.6 & 183.9 & 228.3 & 415.7 & 349.3 & 97.8 & 21.2 \\
\hline
\end{tabular}

Source: Service Center for Basic Engineering Studies - Hydrology, ICE, (2015).

The infiltration coefficient $(C)$ (Schosinsky \& Losilla, 2000) was estimated with Equation 2:

$$
C=\left(K_{\mathrm{p}}+K_{\mathrm{v}}+K f_{\mathrm{c}}\right) \quad(\text { E. } 2)
$$

Where: $K_{\mathrm{p}}$ : Fraction that infiltrates by slope effect (something flat $=$ $0.15) ; K_{\mathrm{v}}$ : Fraction that infiltrates by vegetation cover effect (no vegetation $=0) ; K f_{\mathrm{c}}$ : Fraction that infiltrates by soil texture.

The basic potential infiltration ( $f c: \mathrm{mm} /$ day) (Schosinsky \& Losilla, $2000)$ was determined in the test on the infiltration capacity $(f: \mathrm{cm} / \mathrm{min})$ of mining waste. $K f_{\mathrm{c}}$ is related to $f_{\mathrm{c}}$ as:

$$
K f_{\mathrm{c}}=0.267 \operatorname{In}\left(f_{\mathrm{c}}\right)-0.000154 f_{\mathrm{c}}-0.723 \quad \text { (E. 3) }
$$

The amount of rain ( $\mathrm{mm} / \mathrm{month})$ infiltrating was estimated as:

$$
=0.88 C \times P \quad \text { (E. } 4)
$$

Where: $I$ : infiltration $(\mathrm{mm} / \mathrm{month}) ; C$ : infiltration coefficient; $P$ : monthly precipitation $(\mathrm{mm} / \mathrm{month})$ 


\section{Pollutant loading}

The load of metallic contaminants (CC: $\mathrm{kg} /$ month) in the leachates that originate from the mining waste was estimated considering the concentrations of the leached metals (kinetic test), the infiltrated precipitation that corresponds to the flow of the leachate per month $\left(1 / \mathrm{m}^{2} \mathrm{~s}\right)$ and the total area of the mining waste $\left(\mathrm{m}^{2}\right)$ according to Equation 5:

$$
\mathrm{CC}=\mathrm{Q} \times \mathrm{A} \times \mathrm{C}_{\text {metal }} \times 2.592 \quad \text { (E. 5) }
$$

Where: Q: leachate flow $\left(1 / \mathrm{m}^{2} \mathrm{~s}\right)$; A: mining waste area $\left(\mathrm{m}^{2}\right) ; \mathrm{C}_{\text {metal }}$ : metal concentration $(\mathrm{mg} / \mathrm{l}) ; 2.592$ : conversion factor $(\mathrm{kg} /$ month) (modified from Roldán \& Ramírez, 2008).

\section{Results}

\section{Sizing and characterization of mining waste}

The mining waste in Líbano is in a rectangular collection pile. This allowed the physical dimensioning of the waste: a surface area of $7820 \mathrm{~m}^{2}$, a volume of $54738 \mathrm{~m}^{3}$, an estimated total amount of 106000 tons and an apparent density $\left(\rho_{\mathrm{a}}\right)$ of $1936 \pm 39 \mathrm{~kg} / \mathrm{m}^{3}$.

The mineralogical composition of mining waste in Líbano qualitatively determined by diffractograms in DRX tests was represented by primary non-metallic gangue minerals, such as quartz $\left(\mathrm{SiO}_{2}\right)$, mostly medium-neutralizing minerals such as illite/smectite/montmorillonite $\left(\mathrm{KAl}_{3} \mathrm{Si}_{3} \mathrm{O}_{10}(\mathrm{OH})_{2}\right)$ and chlorite $\left(\left(\mathrm{Mg}_{5} \mathrm{Al}\right)(\mathrm{Si}, \mathrm{Al}) 4 \mathrm{O}_{10}(\mathrm{OH})_{8}\right)$, primary metallic gangue minerals such as pyrite $\left(\mathrm{FeS}_{2}\right)$, and secondary minerals such as gypsum $\left(\mathrm{Ca}\left(\mathrm{SO}_{4}\right)\left(\mathrm{H}_{2} \mathrm{O}\right)_{2}\right)$ and magnetite $\left(\mathrm{Fe}_{3} \mathrm{O}_{4}\right)$. Qualitatively, the minerals that were present mostly are quartz and gypsum, and in smaller proportion pyrite and chlorite and others.

The mining wastes showed yellow-brown coloration on the surface while inside the waste the coloration changed to grey. In this place there was little vegetation and superficially the soil was not compacted. In addition, there was evidence of the entry of people and animals to this site (Figure 3). 
Figure 3. Mining liabilities exposed to a current condition of oxidation and erosion near the San José river in Líbano, Costa Rica

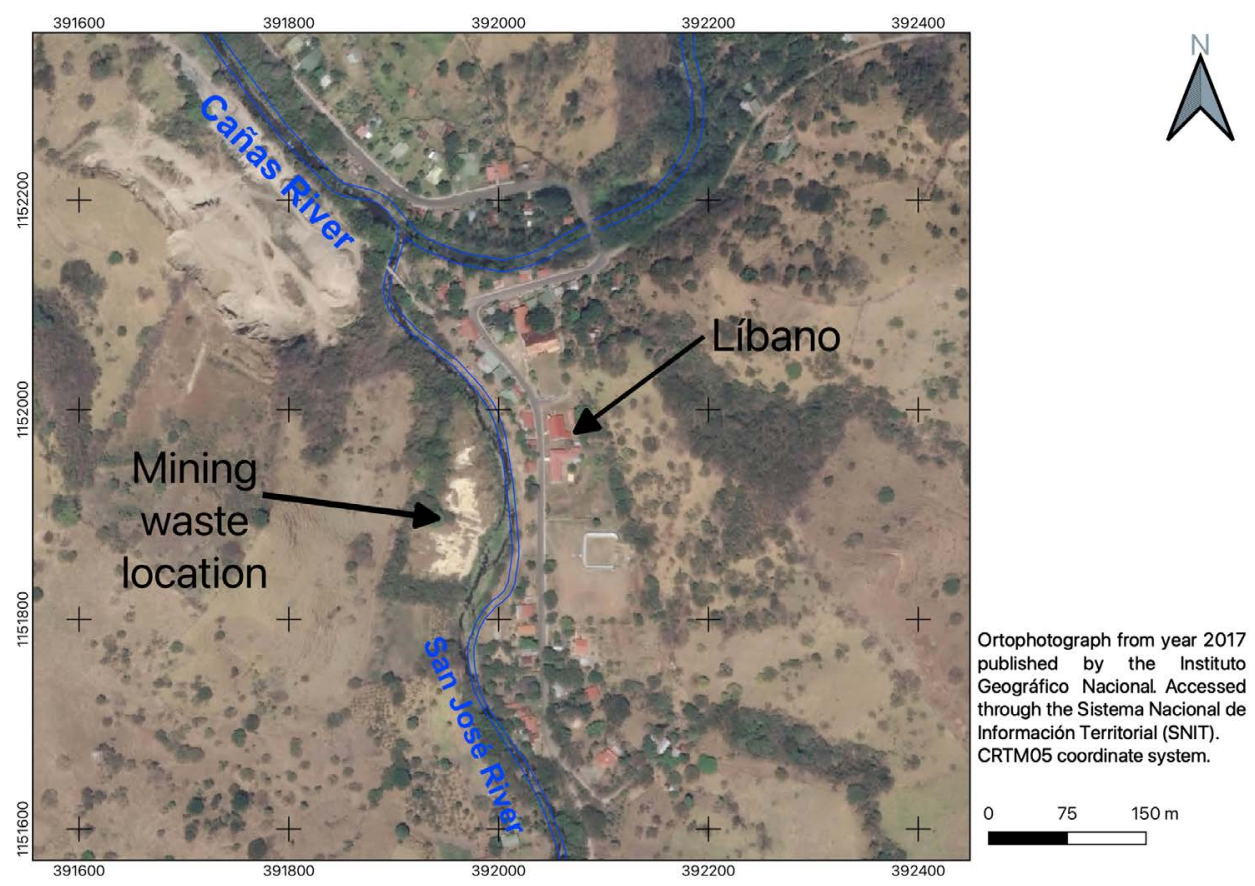

The concentrations of metals in the mine waste in Líbano are shown in Table 2.

Table 2. Concentrations ( $\mathrm{mg} / \mathrm{kg}$ ) and quantity of metals (tons) in mining waste in Líbano, Costa Rica

\begin{tabular}{|c|c|c|c|c|c|c|c|c|}
\hline Sample ID & $\begin{array}{c}\mathrm{Cr} \\
( \pm 2)^{*}\end{array}$ & Cd & $\begin{array}{c}\mathbf{C u} \\
( \pm 3)^{*}\end{array}$ & $\begin{array}{c}\text { Mn } \\
( \pm 9)^{*}\end{array}$ & $\begin{array}{c}\mathrm{Pb} \\
( \pm 24) *\end{array}$ & $\begin{array}{c}\text { Al } \\
( \pm 2)^{*}\end{array}$ & $\begin{array}{c}\text { As } \\
( \pm 2)^{*}\end{array}$ & $\mathbf{H g}$ \\
\hline $\begin{array}{c}\text { Quantification } \\
\text { Limit }(\mathrm{mg} / \mathrm{kg}) * *\end{array}$ & $\begin{array}{c}<< \\
0.40\end{array}$ & $<0.40$ & $<6$ & $<35$ & $<0.30$ & $<0.70$ & $<0.40$ & $<0.20$ \\
\hline \multirow[t]{3}{*}{ Lib A } & 18 & 6.4 & 90 & 387 & 355 & 6500 & 177 & $<0.20$ \\
\hline & 17 & 5.4 & 91 & 346 & 287 & 7600 & 162 & $<0.20$ \\
\hline & 18 & 5.7 & 89 & 335 & 328 & 6600 & 193 & $<0.20$ \\
\hline \multirow[t]{3}{*}{ Lib B } & 29 & 1.4 & 65 & 183 & 345 & 6000 & 189 & $<0.20$ \\
\hline & 30 & 1.2 & 66 & 173 & 417 & 4800 & 202 & $<0.20$ \\
\hline & 27 & 1.6 & 75 & 186 & 407 & 5800 & 223 & $<0.20$ \\
\hline
\end{tabular}




\begin{tabular}{|c|c|c|c|c|c|c|c|c|}
\hline Sample ID & $\begin{array}{c}\text { Cr } \\
(\mathbf{\pm 2})^{*}\end{array}$ & $\mathbf{C d}$ & $\begin{array}{c}\mathbf{C u} \\
(\mathbf{\pm 3})^{*}\end{array}$ & $\begin{array}{c}\mathbf{M n} \\
(\mathbf{\pm 9})^{*}\end{array}$ & $\begin{array}{c}\mathbf{P b} \\
(\mathbf{\pm 2 4})^{*}\end{array}$ & $\begin{array}{c}\text { Al } \\
(\mathbf{\pm 2})^{*}\end{array}$ & $\begin{array}{c}\text { As } \\
(\mathbf{\pm 2})^{*}\end{array}$ & Hg \\
\hline Average \pm SD & $23 \pm 6$ & $3.6 \pm 2.2$ & $79 \pm 11$ & $268 \pm 89$ & $356 \pm 45$ & $6200 \pm 853$ & $191 \pm 19$ & $<0.20$ \\
\hline CV & 26.1 & 61.9 & 14.0 & 33.2 & 12.5 & 13.7 & 10.0 & - \\
\hline Tons & 2.5 & 0.4 & 8.4 & 28.4 & 37.8 & 657 & 20.2 & - \\
\hline
\end{tabular}

* Value of the uncertainty of the analytical measurement; SD: Standard Deviation; CV: Coefficient of Variation.

** Quantification Limit values are those obtained by LASEQ laboratory, UNA.

$(+)$ Reference methods are those used by the laboratory for spectrophotometric measurements.

\section{Leaching and pollutant loading}

Table 3 shows the results of the physical-chemical analysis performed on the leachate from the sample of mining waste subjected to oxidation and Table 4 of the metals analysis performed on the leachate during the kinetic test. The measured parameters show the chemical processes that occurred due to oxidation in mining wastes during the transition from dry-rainy season (Lix 1) and rainy season (Lix 2): the state of the acidity of the medium $(\mathrm{pH})$, the dissolution of the ions (EC), the oxidizing condition of the medium $(\mathrm{ORP})$ and the metal concentrations that are released to the medium by the oxidation of the pyrite (iron and sulfates).

Table 3. Characteristics of leachates obtained in the wet cell kinetic test on mining waste samples from Libano, Costa Rica

\begin{tabular}{|c|c|c|c|c|c|}
\hline Sample & $\mathbf{p H}$ & $\begin{array}{c}\text { Electrical Conductivity } \\
(\mathbf{E C})(\boldsymbol{\mu s} / \mathbf{c m})\end{array}$ & $\begin{array}{c}\text { Redox Potential } \\
(\mathbf{O R P})(\mathbf{m V})\end{array}$ & $\begin{array}{c}\text { Iron } \\
(\mathbf{m g} / \mathbf{l})\end{array}$ & $\begin{array}{c}\text { Sulfates } \\
(\mathbf{m g} / \mathbf{l})\end{array}$ \\
\hline Lix 1 & 4.16 & 3620 & 275 & 1.61 & 3029 \\
\hline Lix 2 & 4.41 & 466 & 219 & 21.5 & 267 \\
\hline
\end{tabular}

Table 4. Metal concentrations in leachates of composite samples (Lix $1+$ Lix 2) of mining waste from Libano, Costa Rica

\begin{tabular}{|c|c|c|}
\hline Metal & Concentration $(\mathbf{m g} / \mathbf{l})$ & Detection Limit (mg/l) \\
\hline Aluminum $(\mathrm{Al})$ & 75.9 & 0.013 \\
\hline Arsenic $(\mathrm{As})$ & 0.411 & 0.006 \\
\hline Barium $(\mathrm{Ba})$ & 0.346 & 0.005 \\
\hline Cadmium $(\mathrm{Cd})$ & 1.23 & 0.002 \\
\hline Copper $(\mathrm{Cu})$ & 3.85 & 0.005 \\
\hline Chrome $(\mathrm{Cr})$ & 0.019 & 0.005 \\
\hline
\end{tabular}


Johanna Rojas Conejo - Francisco Picado Pavón - Andrea Suárez Serrano -

Cornelis A. M. van Gestel - Christian Golcher Benavides - Guillermo Durán Sanabria

Mining environmental liabilities: a potential source of metal contamination

for freshwater ecosystems in Costa Rica

\begin{tabular}{|c|c|c|}
\hline Metal & Concentration (mg/l) & Detection Limit (mg/l) \\
\hline Iron $(\mathrm{Fe})$ & 44.0 & 0.014 \\
\hline Magnesium $(\mathrm{Mg})$ & 107 & 0.014 \\
\hline Manganese $(\mathrm{Mn})$ & 21.8 & 0.005 \\
\hline Mercury $(\mathrm{Hg})$ & $<\mathrm{LD}$ & 0.005 \\
\hline Nickel $(\mathrm{Ni})$ & 1.37 & 0.005 \\
\hline Silver $(\mathrm{Ag})$ & 0.101 & 0.022 \\
\hline Lead $(\mathrm{Pb})$ & 1.03 & 0.019 \\
\hline Zinc $(\mathrm{Zn})$ & 127 & 0.004 \\
\hline Vanadium $(\mathrm{V})$ & 0.100 & 0.022 \\
\hline
\end{tabular}

$<$ LD: Less than the detection limit of the method

The estimated infiltration capacity $(f)$ of mining waste was $239 \mathrm{~mm} /$ day. This low infiltration capacity resulted in the formation of runoff. Based on the results of the infiltration measurements and using the historical precipitation, the behavior of the infiltration rate in the mining waste was estimated (Figure 4). Additionally, the contaminant loads in the leachates generated from the mining waste were estimated (Table 4).

Figure 4. Seasonal patterns in precipitation, infiltration and superficial run-off on mining wastes in Líbano, Costa Rica (2001-2015).

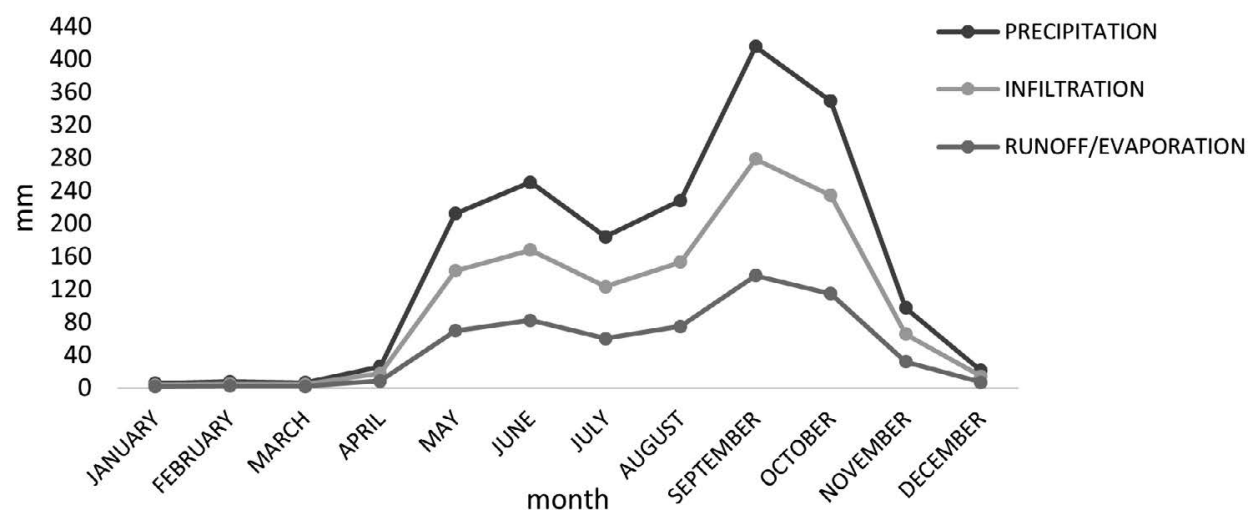


Johanna Rojas Conejo - Francisco Picado Pavón - Andrea Suárez Serrano Cornelis A. M. van Gestel - Christian Golcher Benavides - Guillermo Durán Sanabria Pasivo ambiental minero: una fuente potencial de contaminación por metales para los ecosistemas de agua dulce en Costa Rica
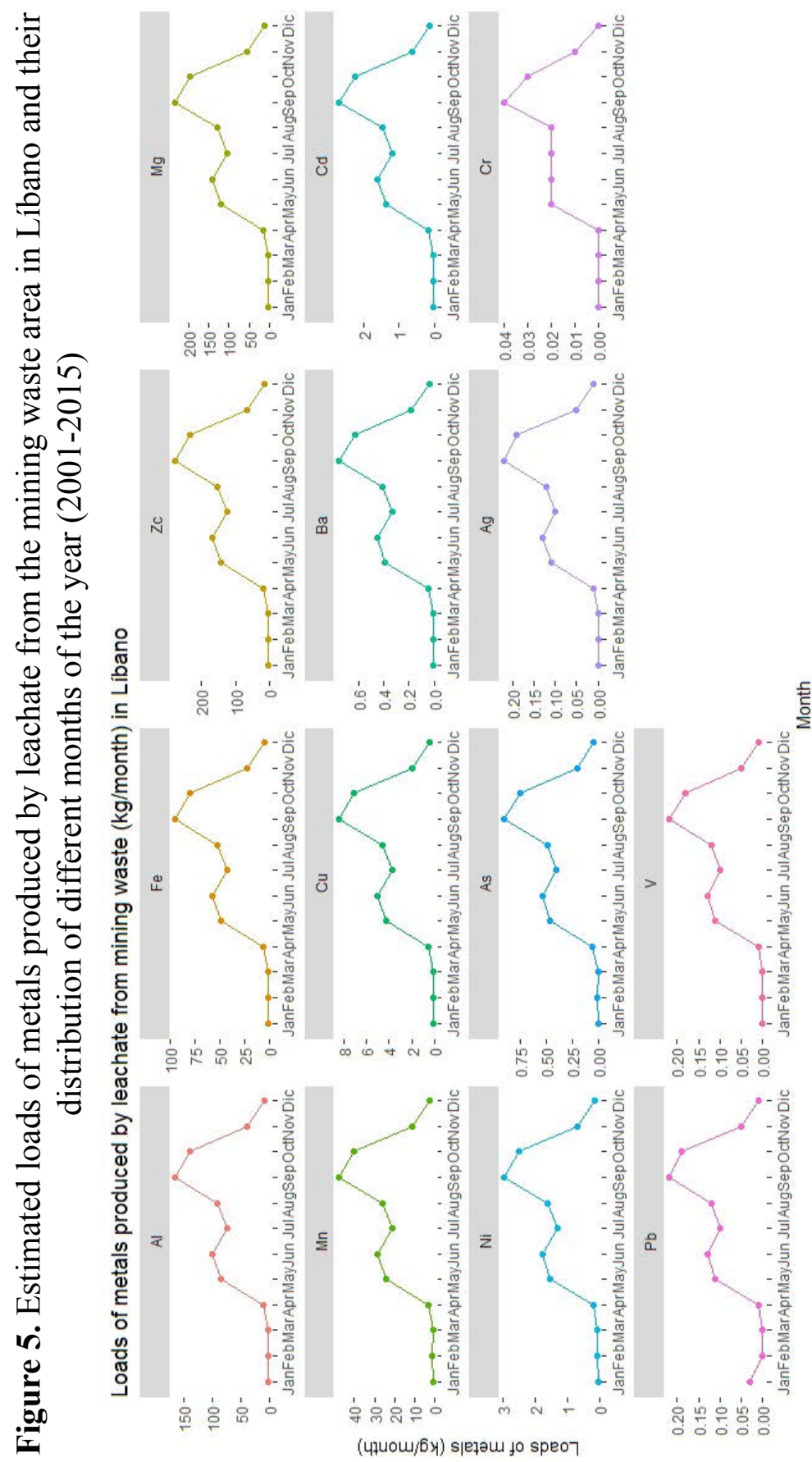

346 Revista Geográfica de América Central. No 68(1)

ISSN 1011-484X • e-ISSN 2215-2563 / Enero-junio 2022

Doi: http://dx.doi.org/10.15359/rgac.68-1.12 


\section{Management of mining liabilities}

The location, environmental condition, metal content and quantity of mining waste have probably affected the San José River for more than 20 years due to contamination by toxic metals. It is necessary to take into account the processes that occur in this mining liability, mainly during rainfall (Figures 3 and 6), to propose management alternatives.

\section{Discussion}

\section{Sizing and characterization of mining waste}

The amount of waste resulting from gold and silver mining in Líbano is $\sim 106000$ tons. This material has a composition related to the geology of the Sado type epithermal deposit of La Esperanza mine and a particle size of less than $150 \mu \mathrm{m}$ (sand texture). This characteristic results in a large surface area exposed to weathering and oxidation (Figure 3), and consequently in the release of metals into the environment (Plumlee \& Nash, 1995), as demonstrated by leachate (wet cell) samples that evidence the ease with which metals are released from mine waste (Tables 3 and 4).

The yellow-brown coloration observed on the surface of the wastes indicates a degree of advanced oxidation (Figure 3), which was confirmed by the ORP and $\mathrm{pH}$ values (Table 3 ) of the leachates indicating an oxidized environment. These conditions lead to acidification and consequently facilitate the release of metals. However, a change in the coloration to grey was observed inside the waste, which is associated with a low degree of oxidation (Corrales \& Martin, 2013).

Due to the high capillarity generated by the fine particles and the degree of compaction of the waste, precipitation drains slowly by gravity through the waste material causing the layers below the dry surface ( $\sim 2$ m deep) to remain permanently saturated with water. This condition makes the waste texture loose and soft, losing resistance during seismic liquefaction, and making it susceptible to water and/or wind erosion (Seed, Tokimatsu, Harder \& Chung, 1985). However, the density of the debris, conferred by the presence of minerals such as gypsum, gives it certain stability, preventing extreme erosion.

Gypsum in the mining wastes may contribute to reducing the dispersion of clays by the mutual repulsion between highly hydrated ions, such as sodium and magnesium. These ions are attracted to the surface of the 
clay particles promoting the flocculation of the soils, which is leading to the formation and stabilization of the waste structure. This allows greater infiltration and percolation of water and air (Chen \& Dick, 2011).

Although the mining wastes were previously subjected to reaction with calcium oxide, the presence of pyrite and its contact with air and/or dissolved oxygen in the percolating water, have led to oxidation (Ritchie, 1994; Robertson, 1994). This natural process occurs slowly producing sulfuric acid and ferric sulfate, which generate acidic drains. These conditions also promote the leaching of metals (Table 4), which consequently presents a risk of contamination of the San José and Cañas Rivers surrounding the area, (González et al., 2008). In order of highest to lowest concentration, the metals present in the leachates were $\mathrm{Zn}>\mathrm{Mg}>\mathrm{Al}>\mathrm{Fe}>\mathrm{Cu}>\mathrm{Ni}>\mathrm{Cd}>\mathrm{P}-$ $\mathrm{b}>\mathrm{As}>\mathrm{Ba}>\mathrm{Ag}>\mathrm{V}>\mathrm{Cr}>\mathrm{Hg}$ (Table 4). The high concentrations of aluminum and manganese can be explained from their presence as natural components of the clays that are present in the waste material. Mercury was present in the waste only at trace levels (Table 4), suggesting that this element was not used in the gold recovery process.

The CV range (Table 2) is an indication of homogenous of the metals distribution, except for cadmium, which shows values greater than $60 \%$. Although the concentrations (tons) of lead and arsenic are higher than those of cadmium in mining waste (Table 4), higher concentrations of cadmium are leached into the river, which represents a greater mobility of this metal in water.

The high concentrations of arsenic in mining waste (Table 2) limit the use of this area for agriculture since it exceeds the guide value for concentration $(12 \mathrm{mg} / \mathrm{kg})$ in soils intended for agriculture (CCME, 2014). Edible terrestrial plants take up arsenic through the roots or through their leaves when the arsenic is airborne. The presence of arsenic and lead (Table 2) in the waste materials limits its residential use, as the concentrations of both elements are above the regulatory values of 70 and $140 \mathrm{mg} / \mathrm{kg}$, respectively (CCME, 2014).

The presence of mining waste in the town of Líbano and its use to fill in crop areas has implied the alteration of the natural conditions of the river, also because of the high concentrations of metals (Table 2). The plants that grow in these fillings show abnormal features like different coloring and morphology than plants of the same species grown in soil free of mining waste material. 


\section{Leaching and loading of contaminants}

Figure 6 shows the dynamics of the processes that interact with mining waste and that condition the release of metals into surface waters in Líbano.

Figure 6. Processes that interact with mining waste

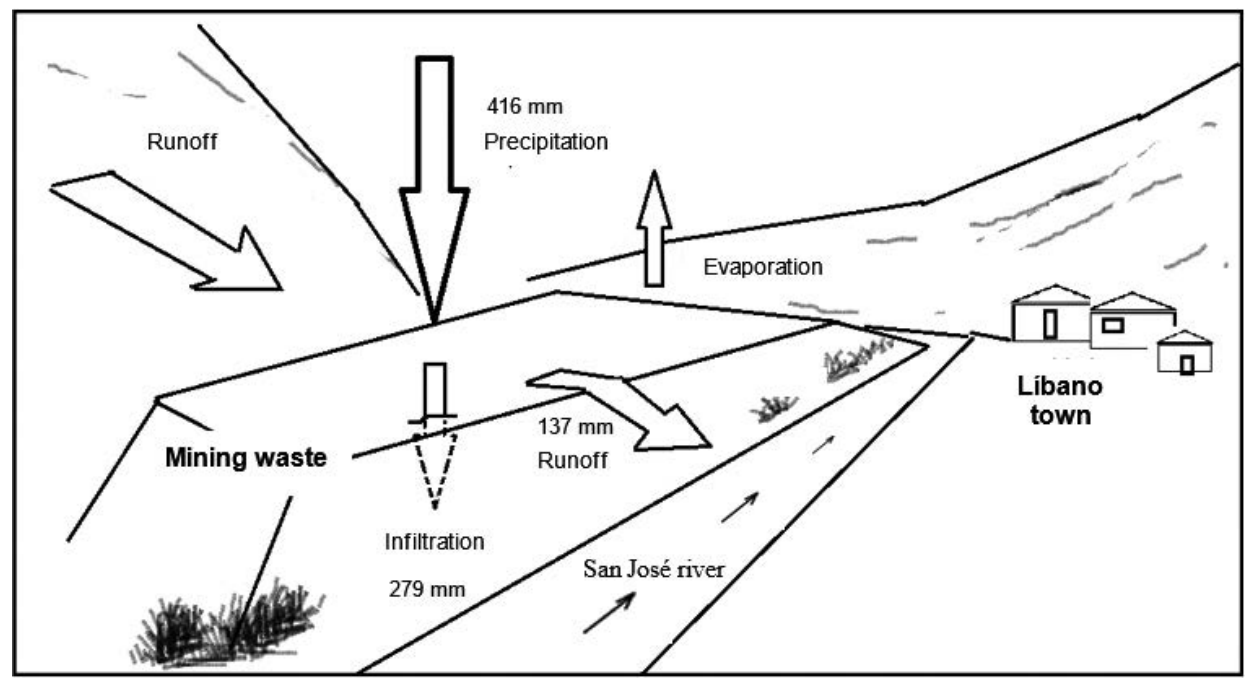

One of the geochemical processes that take place in mining waste during the rainy season and that affects the concentration, distribution or structure of the chemical compounds present, is pyrite oxidation. This oxidation occurs abiotically mainly in the surface layers of the wastes, which have a $\mathrm{pH}$ above 4.0. The balance between water and oxygen (Reaction $\mathrm{R}$. 1) could control this oxidation.

The Lix 1 sample (Table 3 ) represents the leachate that is produced in the transition from the dry to the rainy season, during the first rainfall. The Lix 2 sample is indicative of the leachate that is obtained from mining waste that is humid and oxidized during the rainy season (Table 3 ). Pyrite oxidation can be more rapid during the dry season (Belzile, Chen, Yu-Wei, Mei-Fang \& Yuerong, 2004) with the increase in temperature acting as a catalyst; therefore, it occurs mostly at the surface where air diffusion favors oxidation. 
The pyrite oxidation (Reaction R. 1) produces sulphuric acid, expressed as the concentration of sulfates and the $\mathrm{Fe}^{2+}$ ion (Table 3 ) in solution. This condition causes a higher acidity $(\mathrm{pH} \sim 4)$ and consequently the release of metals to the environment (Table 4).

$$
2 \mathrm{FeS}_{2}(\mathrm{~s})+2 \mathrm{H}_{2} \mathrm{O}+7 \mathrm{O}_{2} \rightarrow 4 \mathrm{H}^{+}+4 \mathrm{SO}_{4}^{2-}+2 \mathrm{Fe}^{2+}
$$

In the second stage (Lix 2 sample), moisture in the cell, oxidation, and acidity, allow $\mathrm{Fe}^{2+}$ to oxidize to $\mathrm{Fe}^{3+}$ (R. 2). This is due to buffering of the acidity produced by the presence of neutralizing minerals in the waste. The $\mathrm{pH}$ may allow a certain amount of $\mathrm{Fe}^{3+}$ to precipitate producing solid ferric hydroxide (R. 3), which occurs at $\mathrm{pH}>4$ (Table 3). The neutralizing minerals present dissolve under these conditions and react with pyrite, which increases the $\mathrm{pH}$ a little, but decreases the ORP potential and the solubility of the sulfates, allowing the formation of gypsum (Table 3).

$$
\begin{aligned}
& 4 \mathrm{Fe}^{2+}+\mathrm{O}_{2}+4 \mathrm{H}^{+} \rightarrow 4 \mathrm{Fe}^{3+}+2 \mathrm{H}_{2} \mathrm{O} \\
& \mathrm{Fe}^{3+}+3 \mathrm{H}_{2} \mathrm{O} \rightarrow \mathrm{Fe}(\mathrm{OH})_{3}(\mathrm{~s})+3 \mathrm{H}^{+}
\end{aligned}
$$

Since the low $\mathrm{pH}$ in the waste allows the dissolution of iron $\left(\mathrm{Fe}^{2+}\right.$ (R. 1) (Rose \& Cravotta, 1998), it may be present in higher concentrations in the material that is transported by leaching or runoff into the San José River. These $\mathrm{pH}$ conditions also favor the dissolution of other minerals that results in increased leachate conductivity (Table 3 ).

The sulphuric acid released in the pyrite oxidation reaction (R. 4) also solubilizes the illite and chlorite, allowing the waste to be neutralized (Craw, 2000). This process provides some aluminosilicates, precipitates the sulfates as gypsum, releases $\mathrm{Ca}^{2+}, \mathrm{Mg}^{2+}, \mathrm{K}^{+}$, and $\mathrm{HCO}_{3}^{-}$ions and contributes to raising the $\mathrm{pH}$ (Langmuir, 1997). This favors the adsorption of metal ions on the surfaces of iron oxides present, forming metal oxyhydroxides and preventing their release into the environment (Corrales \& Martin, 2013). However, the neutralizing capacity of these minerals (aluminosilicates) is of lower intensity due to their low rate of weathering concerning carbonates (Plumlee, 1999).

$$
2 \mathrm{KAl}_{3} \mathrm{Si}_{3} \mathrm{O}_{10}(\mathrm{OH})_{2}+2 \mathrm{H}^{+}+3 \mathrm{H}_{2} \mathrm{O} \leftrightarrow 2 \mathrm{~K}^{+}+3 \mathrm{Al}_{2} \mathrm{Si}_{2} \mathrm{O}_{5}(\mathrm{OH})_{4}
$$


As previously stated, the wastes were treated with calcium oxide $(\mathrm{CaO})$ to eliminate cyanide $(\mathrm{NaCN})$ and buffer acidity by oxidation. However, the oxidation of pyrite by oxygen and water generates four moles of protons $\left(\mathrm{H}^{+}\right)$, so neither the lime nor the natural neutralizing minerals present are sufficient to completely precipitate the sulfuric acid in the form of gypsum and neutralize the surface oxidation processes that have continued for years. At low $\mathrm{pH}$, the metals are displaced from the oxides by protons $\left(\mathrm{H}^{+}\right)$(Triverdi \& Axe, 2000). Consequently, they are released into the precipitating water involving chemical association and transport processes such as leaching and runoff. This suggests that this area is the main source of metal contamination in the San José and later Cañas rivers.

The content of some metals in the leachate was not related to their concentration in the waste. Since, for example, the concentration of chromium in the leachate was about 60 times lower than that of cadmium, even though the amount of chromium (in tons) in the waste was 6 times higher than that of cadmium. Arsenic concentration in the composite leachate was 9 times lower than that of copper, but its content in tons in the waste was more than 2 times higher than that of copper (Tables 2 and 4).

Aluminum and manganese were metals found in large quantities in waste (Table 2) and showed high tendency to leach (Figure 5). This may be explained from their being part of the chemical structure of neutralizing clays or minerals, which are dissolved upon pyrite oxidation and therefore more easily released. In addition, the gypsum present in the wastes may react with the soluble aluminum contributing to its release (Chen \& Dick, 2011).

Rainfall peaks in September (Figure 4) resulted in increased infiltration $(279 \mathrm{~mm})$ and surface runoff/evaporation $(137 \mathrm{~mm})$. During this month, the water that precipitated in the mountain (Figure 6) adjacent to the waste zone (cut off water from the San José river basin) also formed part of the volume that leached or ran off from this zone. In the months with less precipitation, the largest volume of water infiltrated and the remaining water evaporated (Figure 4). These processes occurred mainly at the surface level because the innermost layers of the waste were saturated, therefore, the water that infiltrated travelled according to the slope of the land, saturating the lower parts of the waste zone until it reached the San José river (Figure 6). 
The metals that were released were transported from the mining waste area to the river by the infiltrated water, as well as probably by the water that ran off the surface. The material gypsum did not contribute to the acidity of the environment. Its presence is associated with the ubiquity of calcium and sulfate; however, the latter is highly soluble $(241 \mathrm{~g} / \mathrm{l})$, so it dissolved easily during rainfall contributing with the dragging of materials from the waste zone surfaces to the river (Seal II \& Foley, 2002). Another way in which contaminants were also dragged from the mining waste was when the waters of the San José river contacted the waste during the rainy season, dissolving the material and incorporating the metals and other chemical compounds present.

\section{Management of mining liabilities}

Líbano is located in a seismic zone affected by the Cañas fault, with the danger of landslides and flooding (Arce, 2004), a condition that could cause mining waste to suffer changes in its structural properties, related to the behavior of its geotechnical characteristics in terms of stability, infiltration, and deformation. Therefore, the management of this mining liability should be done through the design of structures that contribute to keeping the waste stable and free of oxidation and reduce the infiltration of water in the mountain of wastes to avoid leaching metals to rivers.

\section{Conclusion}

The presence of quartz minerals, gypsum, pyrite, and chlorite gives the mining waste structural stability. However, weathering constantly erodes its structure while facilitating the permanent oxidation of its surface layers. Acidic conditions are created that favour the release of metals such as $\mathrm{Pb}, \mathrm{As}$, and $\mathrm{Cd}$ to the water percolating through the waste material in the dry-rainy transition period and dry season. Thus, the large amount of waste and its high concentrations of metals make these mining liabilities in Líbano a source of pollution for the surface water, sediments and benthic macroinvertebrates of the San José river. The high concentrations of $\mathrm{Pb}$ and As contained in the mining liabilities make these soils unsuitable for agricultural or residential purposes, due to the risk they pose to the health of man and the environment. Management alternatives at this site should seek to physically and chemically stabilize the structure and prevent surface oxidation. 


\section{Acknowledgments}

We appreciate the collaboration provided by the Water Resources Center for Central America and the Caribbean (HIDROCEC-UNA), the Center for Aquatic Resources Research (CIRA/UNAN-Managua), the Geochemistry and Geology laboratories (CSRG-ICE), the Laboratory for Chemical Analysis and Services (LASEQ-UNA), the Laboratory for Biotechnology (UNAN - Managua), the Service Center for Basic Engineering Studies - Hydrology (ICE) and the German Academic Exchange Service (DAAD).

\section{References}

Arce, R. (2004). Resumen Diagnóstico Cuenca Cañas-Lajas. Cañas, Guanacaste: Proyecto Redes Comunitarias para la Gestión del Riesgo en Costa Rica.

APHA. (1995). Standard Methods for the Examination of Water and Wastewater (19 ed). American Public Health Association/American Water Works Association/Water Environment Federation, Washington, DC.

APHA. (2005). Standard Methods for the Examination of Water and Wastewater (21 ed.). American Public Health Association/American Water Works Association/Water Environment Federation, Washington DC.

Belzile, N., Chen, Yu-Wei, C., Mei-Fang, C. \& Yuerong, L. (2004). A review of pyrrhotite oxidation. Geochemical Exploration, 84 (2), 6575. doi: https://doi.org/10.1016/j.gexplo.2004.03.003

Camprubí, A., González-Partida, E. \& Levresse, G. (2003). Depósitos Epitermales de alta y baja sulfuración: una tabla comparativa. Boletín de la Sociedad Geológica Mexicana, 56(1), 10-18.

Canadian Council of Ministers of the Environment (CCME). 2014. Canadian Soil Quality Guidelines for the Protection of Environmental and Human Health.

Candeias,C., Ferreira da Silva,E., Salgueiro, A.R., Pereira, H.G., Reis, A.P., Patinha, C., Matos, J.X. \& Ávila, P.H. (2011). Assessment of soil contamination by potentially toxic elements in the aljustrel mining area in order to implement soil reclamation strategies. Land Degradation \& Development, (22), 565-585. doi: https://doi.org/10.1002/ldr.1035 
Castillo, M. R. (1997). Recursos minerales de Costa Rica: génesis, distribución y potencial. San José, Costa Rica: Editorial de la Universidad de Costa Rica, 58. Retrieved from: https://www.academia. edu/28107421/RECURSOS_MINERALES_DE_COSTA_RICA_-ROLANDO CASTILLO MUNOZ

Chen, L. \& W.A. Dick. (2011). Gypsum as an agricultural amendment: General use guidelines. The Ohio State University Extension, Columbus. Retrieved from: https://fabe.osu.edu/sites/fabe/files/imce/ files/Soybean/Gypsum\%20Bulletin.pdf

Cooke, D. (1987). Ore potential of the Compañia Minera Esperanza Property, Guanacaste province, Costa Rica: D.L. Cooke and Associates Ltd., Technical Report, 5.

Corrales, P. D \& Martín, R. F. (2013). Evaluación de la peligrosidad de jales de zonas mineras de Nicaragua y México y alternativas de solución. Boletín de la Sociedad Geológica Mexicana, 65(3), 427-446.

Craw, D. (2000). Water-rock interaction and acid neutralization in a large schist debris dam, Otago, New Zealand. Chemical Geology, 171(12), 17-32. doi: https://doi.org/10.1016/S0009-2541(00)00231-X

González, S. M.R., Sánchez, T.S.A., Márquez, H. C., Lizárraga, M. L.G \& Durán, D. M.C. (2008). Oxidación de Jales ricos en pirita en un reactor a escala de banco. Revista Latinoamericana de Recursos $\mathrm{Na}$ turales, 4 (2) ,130-138.

International Centre for Diffraction Data. (1997). Powder Diffraction File Sets 1-47.

Instituto Costarricense de Electricidad (ICE). (2015). Estación meteorológica Líbano (1984 al 2015), Centro de Servicios Estudios Básicos de Ingeniería - Área de Hidrología.

Instituto Meteorológico de Costa Rica (IMC). (2010). Mapa, CAPA estado actual del tiempo. Retrieved from: https:/www.imn.ac.cr/

Jambor, J. L. (1994). Mineralogy of sulfide-rich tailings and their oxidation products. In: J. L. Lambor, \& D. W. Blowes. (Eds.). The environmental geochemistry of sulfide mine-wastes. Mineralogical Association of Canada, Short Course Handbook, 22,103-132.

Jarup, L. (2003). Hazards of heavy metal contamination. Brithis Medical Bulletin, 68(1), 167-182. doi: https://doi.org/10.1093/bmb/ldg032 
Kyungmin, K., Juhee, K. \& Seunghun, H. (2018). Soil attenuation of the leaching potential of mine-related metallic elements ( $\mathrm{Zn}, \mathrm{As}$, and $\mathrm{Cd})$ under different leachate solute compositions. Environmental Management, 222, 402-408. doi: https://doi.org/10.1016/j.jenvman.2018.05.096

Langmuir, D. (1997). Aqueous Environmental Geochemistry. New Jersey: Prentice-Hall.

Naicker, K., Cukrowska, E. \& McCarthy,T. S. (2003). Acid mine drainage arising from gold mining activity in Johannesburg, South Africa and environs. Environmental Pollution, 122(1), 29-40. doi: https://doi. org/10.1016/s0269-7491(02)00281-6

Navarro, M.C., Pérez-Sirvent, C., Martínez-Sanchez, M.J., Vidal, J., Tovar, P.J., $\&$ Bech, J. (2008). Abandoned mine sites as a source of contamination by heavy metals: A case study in a semi-arid zone. Geochemical Exploration, 96(2-3), 183-193. doi: https://doi.org/10.1016/j.gexplo.2007.04.011

Nicholson, R.V. (1994). Iron-sulfide oxidation mechanisms: laboratory studies. In D. W. Blowes \& J. L. Jambor. (Eds.). The Environmental Geochemistry of Sulfide Mine Wastes (163-183). Mineralogical Association of Canada, Ontario.

Roldán, G. y Ramírez, J. J. (2008). Fundamentos de Limnología Neotropical. Medellín: Universidad de Antioquia.

Ritchie, A. I. (1994). Sulfide oxidation mechanisms: controls and rates of oxygen transport. In D. W. Blowes \& J. L. Jambor. (Eds.). Environmental Geochemistry of Sulfide Mine Wastes (201-245). Mineralogical Association of Canada, Ontario.

Plumlee, G.S. \& Nash, J.T. (1995). "Geoenvironmental models of mineral deposits; fundamentals and applications". In E. A. du Bray. (Ed.). Preliminary Descriptive Geoenvironmental Models of Mineral Deposits. U.S. Geological Survey, Open-File Report, 1-9.

Plumlee, G.S. (1999). The environmental geology of mineral deposits. In G. S. Plumlee \& M. J. Logsdon. (Eds.), The Environmental Geochemistry of Mineral Deposits, Part A: Processes, Techniques, and Health Issues: Economic Geology, v. 6A, 71-116.

Pruvot, C., Douay, F., Hervé, F. \& Waterlot, C. (2006). Heavy Metals in Soil, Crops and Grass as a Source of Human Exposure in the Former Mining Areas. Soils and Sediments, 6, 215-220. doi: https://doi. org/10.1065/jss2006.10.186 
Robertson, W.D. (1994). The physical hydrology of mill-tailings impoundments. In D. W. Blowes \& J. L. Jambor. (Eds.). Environmental Geochemistry of Sulfide Mine Wastes (1-17). Mineralogical Association of Canada, Ontario.

Rösner, T. \& Van Schalkwyk, A. (2000). The environmental impact of gold mine tailings footprints in the Johannesburg region, South Africa. Bulletin of Engineering Geology and Environmental, 59: 137-148. doi: https://doi.org/10.1007/s100640000037

Rose, A. W., \& Cravotta, C. A. (1998). III. Geochemistry of Coal Mine Drainage. In Coal Mine Drainage Prediction and Pollution Prevention in Pennsylvania. Pennsylvania: Department of Environmental Protection. Retrieved from: https://www.dep.state.pa.us/dep/deputate/minres/districts/CMDP/chap01.html.

Schosinsky, G. \& Losilla, M. (2000). Modelo analítico para calcular la infiltración con base en la lluvia mensual. Revista Geológica de América Central, 23, 44-55.

Seal II, R. \& Foley, N. K. (2002). Progress on Geoenvironmental Models for Selected Mineral Deposit Types. In P. L. Younger, S. A. Banwart \& R. S. Hedin. (Eds.). Mine Water, Hydrology, Pollution y Remediation. Kluwer Academic Publishers. Bodmin, Cornwall, Reino Unido.

Seed, H., Tokimatsu, K., Harder, L. \& Chung, R. (1985). Influence of SPT Procedures in Soil Liquefaction Resistance Evaluations. Geotechnical Engineering, ASCE, 111(12).

Singer, D.A., Norman J.P., Bagby, W.X., Cox, D.P \& Ludington, S. (1990). Evaluación de los Recursos Minerales de Costa Rica. Revista Geológica América Central, 11, 1-25.

Singh, AN., Zeng, DH. \& Chen, FS. (2005). Heavy metal concentrations in redeveloping soil of mine spoil under plantations of certain native woody species in a dry tropical environment, India. Environmental Sciences, 17(1), 168-174.

Sobek, A.A., W. A. Schuller, J.R. Freeman \& R.M. Smith. (1978). Field and laboratory methods applicable to overburdens and mine soils. EPA600/2-78-054. U.S. Environmental Protection Agency, Cincinnati, OH.

Triverdi, P. \& Axe, L. 2000. Modelling Cd and $\mathrm{Zn}$ sorption to hydrous metal oxides. Environmental Science \& Technology, 34(11), 22152223. doi: https://doi.org/10.1021/es991110c 